\title{
Developing MATMINO (Domino Mathematics) Learning Media in Grade 7 Algebra Material
}

\author{
Sri Wahyuningtyas ${ }^{1}$, Leonard ${ }^{(2, *)}$, Natalia Tri Astuti ${ }^{3}$ \\ ${ }^{1,2}$ Program Studi Pendidikan Matematika, Universitas Indraprasta PGRI, Jl. Nangka No. \\ 58c Tanjung Barat, Jakarta Selatan, DKI Jakarta, Indonesia \\ ${ }^{3}$ Program Studi Teknik Informatika, Universitas Indraprasta PGRI, Jl. Nangka No. 58c \\ Tanjung Barat, Jakarta Selatan, DKI Jakarta, Indonesia
}

Received: August 08, 2021

Revised: February 03, 2021

Accepted: February 09, 2021

\begin{abstract}
Math Domino Learning Media game is developed to meet the needs of students because it has not been the availability of learning media to help the process of learning mathematics. The research aims to determine the existence of learning media to improve the development of game media through the learning media of Domino math game and the feasibility of Domino math learning. The subjects of this study were 7 th grade students of JHS in Jakarta which consisted 25 students. This research type is Research Development (R\&D) with ADDIE model. This investigation consists of several steps, namely: (1) Analysis, (2) Design, (3) Development, (4) Implementation, (5) Evaluation. Validity test was done by 6 validators. Based on the results of research, it can be concluded that development of learning media MATMINO can be used on mathematics subjects. The results show that the average gained from material experts is 4,33 (very decent) and the average gained by media experts is 4,37 (very decent). Student's response to learning media of MATMINO was in very good category with 4.33 average score. As a result, it is stated that domino mathematics learning media on algebra material can be used in the process of learning mathematics activities.
\end{abstract}

Keywords: Mathematics Learning Media, Domino Math Game, ADDIE

(*) Corresponding Author:

E-mail: leo.eduresearch@gmail.com

How to Cite: Wahyuningtyas, S., Leonard, L., \& Astuti, N.T. (2021). Developing MATMINO (domino mathematics) learning media in grade 7 Algebra material. Formatif: Jurnal Ilmiah Pendidikan MIPA, 11 (1): 1-14. http://dx.doi.org/10.30998/formatif.v11i1.8158

\section{INTRODUCTION}

Advancing or developing a country can be determined by the quality of education and human resources. Education is a pillar of life of the Nation (Cinnirella \& Schueler, 2018; Setiawati, 2017; Anwar, 2016), the advancement the education of a nation is increasingly determined by the Society (Hanushek \& Woessmann, 2020; Suciati, 2015). Sekuloska (2014) and Leonard \& Wibawa (2020) asserted that the knowledge and skills of human development and resources were obtained from ongoing education and training processes. This is in line with the determinants of establishing a better life, including the nation's life is build human resources (Manullang, 2013; Donou-Adonsou, 2019). Sua (2013) and Sudarsana (2016) ) assert that education can make the development of human resources faster to understand and be ready in the face of change and development of the nation.

In the educational world, mathematics is no longer a matter of foreign sounding. Mathematics is a mandatory subject from elementary to higher education. James Joseph Sylvester (Johnson \& Steinerberger, 2019) ) reveals that mathematics relates to reasoning 
based on thought processes. Mathematics is a scientific thinking that students must be mastered in an education unit. Serlina \& Leonard (2019) reveals that mathematics is not a science that is only used for himself, but it is essential for science. This is what makes mathematics as a science of knowledge (Yosefa \& Hesvi, 2014; Novitasari \& Leonard, 2017) so, mathematics is the main key to other knowledge learned in school. Mathematics is not only for calculations but also used by other sciences for the development of science (Muhtadi, 2019). Students complain that mathematical subjects are an elusive (Mahendra, 2017; McGowen \& Tall, 2013), scary (Ruff \& Boes, 2014) and boring (Eng \& Fah, 2011) caused by students have not understood the concept so that it impacts the connection conceptually (Ramli, 2013). Sahara (2017) reveals that mathematics is very beneficial in its role in everyday life, making students disciplined, honest, hard work, creative, curious, self-reliant, communicative and responsible (Surat, 2016); therefore, it is necessary that the students interested in mathematics.

Unattractive Mathematics (Attard \& Holmes, 2020) ) is one of the reasons Mathematics is less preferable because the learning strategy that the teacher has delivered is less precise. Teachers must use appropriate variations in their learning strategies. The monotonous delivery of teachers will cause students to be less interested in learning. Students feel bored and less interested in following the lesson, so there is no motivation in him to understand the material that his teacher delivered. Motivation has a very important role in the learning process (López-Fernández, Ezquerro, Rodríguez, Porter, \& Lapuerta, 2019; Law, Geng, \& Li, 2019; Mayangsari \& Mahardhika, 2019). The lack of motivation to make students do not care about the mathematics lesson, making the results of mathematics still low.

The learning of mathematics that has been implemented by teachers uses conventional approaches. As Lin, Wang, \& Yang (2018) The lack of student involvement in the learning process is an educational problem for every country, teacher-centered learning that is in the opinion of Leonard \& Nisa (2020) that the majority of teachers in Indonesia only conduct one-way and classical learning to cause low student responses in the interest of learning mathematics. It can cause students to not actively participate so that in following the learning of students there is no curiosity, no questions and no learning interest (Anggo \& La Arapu, 2018). Problems that often occur in the field during the learning process that has been done so that the low student learning outcomes are not entirely due to outside factors such as busy teachers, household conditions, environment and others. There are certainly many weaknesses influenced by the teacher's own factors such as the willingness to prepare better materials (Wibawa \& Leonard, 2020), the will of the teacher himself to apply the teaching methods that have been obtained in the college. In addition, teachers are also less able to develop teaching skills that can attract student's attention and stimulate students to learn. Teachers should provide activity to students (Diego, Carlos, \& Jose, 2019) ) to solve problems based on his or her ability (Yuliati, 2017).

One of the ways teachers can regrow the spirit and attract students in learning is through the use of learning media. The use of learning media is important in learning objectives. Media learning can serve as aids in the learning process (Nugroho, Putra, Putra, \& Syazali, 2017) then the role and function of learning media should not be ignored. A quality learning process, one of them, always provides a variety of learning resources or learning media. The selection of learning media requires media that can change the student's perception of mathematics learning so that learning becomes more enjoyable and can increase the motivation and learning interest of students. The role of teachers is also a factor that can influence students to grow interest in learning, in order to improve the effectiveness and efficiency of learning. The effectiveness of the learning process is influenced by the teachers and learning media used. Most teachers do not use the learning media when delivering subject matter. This is unfortunate learning in the classroom using 
only the equipment of markers, whiteboards and power points. The equipment's use factor leads to one-way learning. In other factors, the school only has a certain learning media e.g., on a space-building material. Some schools have no learning media.

Domino's media game is one of the game media that can cause interesting learning activities and help the atmosphere of learning to be happy, lively and relaxed. The learning process is an activity that needs to be designed properly and correctly in order to influence the students to achieve the educational objectives (Karimah, Supurwoko, \& Wahyuningsih, 2014). The objective of education is essentially to deliver students to changes in the behavior of both intellectually, morals and socially in order to live independently as individual and social beings. These objectives can achieve so that students interact with the learning environment organized by the teacher through the learning process.

Domino Game Media is one of the developments of visual based print media, because the media is generated through the process of printing which generates text, graphics, and photos or images displayed on the card. Domino's Media card game can enhance student learning interactions in the classroom. Sahman (2019) explained that there was an increase in teacher activity, and students using the Domino game media. This proves the relation between the activity of students in class with student learning outcomes. The use of this game all students can do games that do not require special skills in Coverflow, as long as accompanied by instructions for use. Developing MATMINO (Domino Mathematics) Learning Media in Grade 7 Algebra Material Researchers hope the creation of this mathematical learning medium becomes an alternative to be the solution of the instructional problem in math.

\section{METHODS}

This research, using Research and Development methods (R\&D). The resulting product later shaped visual-based print media. This product developed to develop Domino math learning media for algebraic material in accordance with curriculum 2013 revision 2017 that applies to students at Junior High School 209 Jakarta.

The model of development that is referenced and used in research and development of learning Media is the model ADDIE (Analysis, Design, Development, Implementation, and Evaluate). The initial stages of this research are the needs assessment analysis, audience target analysis, analysis of topics and tasks obtained after conducting problem identification through the results of initial need analysis survey, which is the delivery of learning that is monotonous and one-way, limited use of learning media so that the need for additional learning media. The second stage is the design stage used to create the Learning Media Design Mathematics Domino. This stage is tailored to the outcome of the need's analysis including the design of product designs materials, game rules drafting, questions, points, and answers, arranging product valuation instruments. The third stage is the development stage. This stage researchers began to produce learning media, namely physical form, so that this stage will produce. Prototype produced and tested by experts to be given quality assessment and commentary and suggestions and improvements for the repair process. The Prototype has been validated by material and media experts. The of stage is the development stage and has been declared worthy by the experts, will be implemented or tested to the user in a real situation in the field. The implementation stage is done to students to respond to learning media. However, at this stage of charging is done online because of the effort to meet students in groups. The fifth stage is analyzing the feasibility of mathematics learning media that has been developed. 


\section{RESULTS \& DISCUSSION}

\section{Results}

The development of media uses the model with ADDIE stage (Analysis, Design, Development, Implementation, and Evaluation). Based on the research conducted, there is a learning media in mathematics Domino consisting of five stages.

\section{Analysis}

This analysis there are three stages conducted based on the results of preliminary interviews structured in the teacher, namely, analysis of need assessment, audience target analysis and analysis of tasks.

a. Basic Needs analysis

Structured interviews on three teachers obtained information that the use of media game learning has not been used. The average learning medium used by teachers is still limited to PowerPoint, projector, laptop and props in social arithmetic material and number operations, and teachers feel difficulties in delivering algebraic material because the material is abstract.

b. Target Analysis

Age 13-15 students experience cognitive development that can understand and assume about the things that are imaginative. Students can understand the ability of symbolic thinking. So that making children still need media for learning resources. Expressed by one teacher that students should have direct involvement in seeing or touching the media as an understanding of the material being taught. The results of interviews with teachers are informed that students are more likely to play. Students who feel saturated when doing their learning will be more interested in doing other things like chatting with friends or doing other activities. The tendency to reduce the learning interest of students can be anticipated to create learning media that carries the theme of playing while learning.

c. Task Analysis

Analysis of the task is done by analyzing the basic tasks that students must be mastered can achieve minimal competence. The task analysis is obtained from core competencies and basic competencies. Algebraic materials include 2 basic competencies.

\section{Design}

a. $\quad$ Designing Learning Media Design

Completeness in the Learning Media game Math Domino is a 1-piece game board mathematics Domino, 1 set of questions (54 pieces), game rules, material summaries and discussion of the question. Designing the design as a base of Matmino card media products. The Prototype of the back MATMINO card contains a card design and motivational sentence. This card measures $6 \mathrm{~cm} \times 10 \mathrm{~cm}$. Prototype Card problem MATMINO, this section contains the questions that have been determined. This card measures $6 \mathrm{~cm} \times 10 \mathrm{~cm}$. Prototype MATMINO Board, this board is used as a table while playing. Designed to be folded in size $25 \mathrm{~cm}$ x $36 \mathrm{~cm}$. Prototype Game manual MATMINO, this section contains the game guide MATMINO, the material summary and discussion of the card in the design displays the form of cards and the question to make it easier for students to find answers. Game manual MATMINO designed size $13 \mathrm{~cm}$ x $18 \mathrm{~cm}$. Problem on the card MATMINO has a variety of different problems. 
One of the same answers has eight different questions. A set of cards consisted of 56 questions.

b. Drafting rules, problems and key answers

This stage creates rules of domino math games, materials, questions and answers. Rules of the Domino math game are almost the same as the Domino game rules in general, however. Before starting the game, students first read the material summaries and examples of the questions that have been provided in the Handbook, and then start the game MATMINO. MATMINO card distributed by MINO, each player gets seven cards. MINO shares a blank paper for scribbles. Before starting the player game on a card that has been held for 15 minutes. The game starts from the first player, then the second player starts from the right side of the first player. The first player is tasked with issuing cards. Players who take turns pairing cards but cannot answer should say "MATMINO" and lose turn pair cards. The game finishes when the card runs out or times out. The winning criteria in the card game are out of the first time or the rest of the cards held at least each. The material and questions contained in the media Learning game MATMINO is adapted to the material contained in the school syllabus in the applicable algebra. Researchers made 54 questions and 54 key answers and material summaries. 54 Problem loading 2 core competencies is loaded with a level of difficulty from easy to difficult. The problem contains calculations and questions about the story.

c. Develop product valuation instruments

The instrument used to collect data is a polling. Poll is an information gathering tool by submitting a question in writing to be answered in writing by the respondent (Nugraha \& Sundayana, 2014). Poll in the form of questions to explore information in collecting data such as the feasibility of learning the math of dominoes, accuracy of contents, design, and student response after using the math game media Domino. The polling used in this development study to obtain data from material experts, media experts and students as content of evaluating the development learning product or media. The appraisal of the polling uses the Likert scale (scale five). Alternative answers used in polls are SS (very concur) $=5, \mathrm{~S}$ (concur) $=4, \mathrm{R}($ doubtful $)=3$, TS $($ disagree $)=2$ and STS $($ very disagree $)=1$. Conversion of scoring result score into value with five categories according to (Widyoko, 2012).

Table 1. Scoring conversion of scoring results into values with five categories

\begin{tabular}{cccl}
\hline Score & Formula & Value & Classification \\
\hline 5 & $x \geq 4,21$ & $\mathrm{~A}$ & Very decent \\
4 & $3,41 \leq x \leq 4,20$ & $\mathrm{~B}$ & Worth \\
3 & $2,61 \leq x \leq 3,40$ & $\mathrm{C}$ & Decent enough \\
2 & $1,81 \leq x \leq 2,60$ & $\mathrm{D}$ & Less decent \\
1 & $x \leq 1,8$ & $\mathrm{E}$ & Very less decent \\
\hline
\end{tabular}

\section{Development}

Stages of development include product manufacture, validation of product usability and repair or revision. Product creation consists of designing products using the application Canva, Corel Draw X7 and Adobe illustrator. MATMINO card material is the paper art carton 310 gram, for the manufacture of this card is made with two pieces of paper art carton 310 grams to be more durable coated with stickers. The creation of board games made of wood, with stickers of 210 grams art carton made of glossy wood. The material uses for the packaging is a coated 260 grams art carton. The creation of game guides, 
material summaries, and discussions is found in one handbook made with 100 grams of paper material, the cover made Doff paper.

The products are developed in the form of print media games. The game comes along with summary of the material and discussion of questions. Here is the result of the realization of developed learning media.
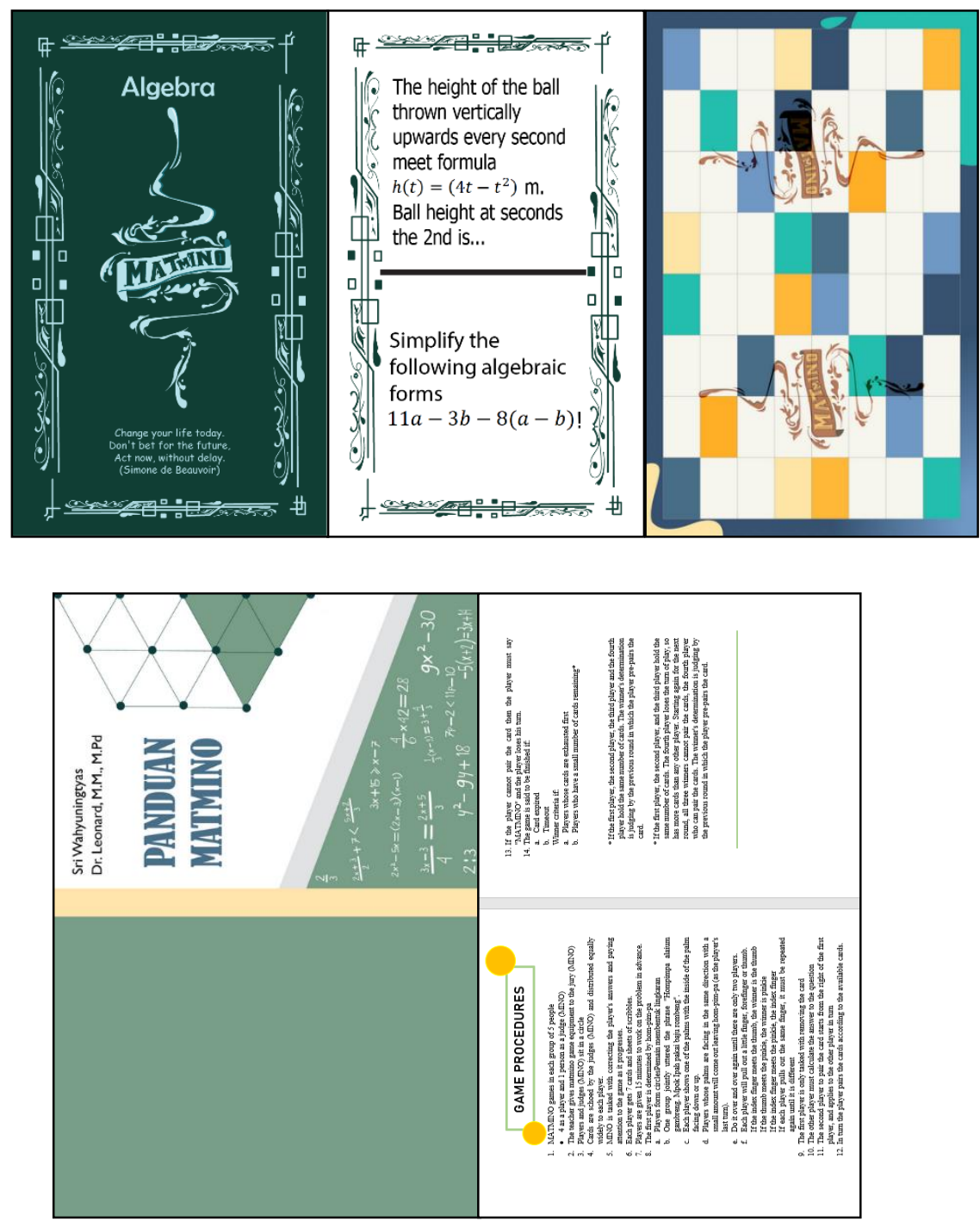

Figure 1. Design Media Learning MATMINO

The feasibility of MATMINO card media can be known from the results of the validation assessment by the material members ( 2 lecturers and 2 teachers) and media experts (2 Mathematics education lecturers). Here's the assessment by the six validators: 
Table 2. Domino Math card Media Feasibility Validation Results

\begin{tabular}{clccl}
\hline Number & \multicolumn{1}{c}{ Validator } & $\begin{array}{c}\text { Number of } \\
\text { scores }\end{array}$ & Average & Description \\
\hline 1 & Material expert Lecturer 1 & 87 & 4,14 & worthy \\
2 & Material expert Lecturer 1 & 98 & 4,67 & very decent \\
3 & Expert Material Teachers 1 & 90 & 4,28 & very decent \\
4 & Expert Material Teachers 1 & 86 & 4,09 & worthy \\
5 & Media Experts 1 & 84 & 4,2 & worthy \\
6 & Media Experts 1 & 91 & 4,33 & very decent \\
& Average end & 536 & 4,28 & very decent \\
\hline
\end{tabular}

Judging by the table 2 the results of the validation are known that the average validation result is 4.28 included in the very decent category that can be used in the learning process. After performing expert validation (media experts and materials). Researchers do revision according to advice from experts. Here is a view before and after the revision is presented in table 3 .

Table 3. Critique and learning Media suggestions

\begin{tabular}{|c|c|c|}
\hline Number & Criticism and suggestion & Action \\
\hline 1 & $\begin{array}{l}\text { Add the opening sentence for the bottom } \\
\text { question type. } \\
11 a-2 b-8(a-b) !\end{array}$ & $\begin{array}{l}\text { Simple the following } \\
\text { form of algebra } 11 a- \\
3 b-8(a-b) !\end{array}$ \\
\hline 2 & $\begin{array}{l}\text { to question the form of algebraic division } \\
\text { should be likened its symbol. } \\
\text { For example } \\
\frac{30 x^{2}-55 x+25}{5} !\end{array}$ & $\begin{array}{l}\text { Simple the following } \\
\text { form of algebra } \\
\left(30 x^{2}-55 x+25\right) \div 5 \text { ! }\end{array}$ \\
\hline
\end{tabular}

\section{Implementation}

This stage is a phase for knowing the feasibility of the resulting product, which is the Domino math game media in algebraic material for the VII class. Students are given a poll that contains the response items to assess the feasibility of the Domino math game media from the user's response aspect. Based on a small group field trial involving a grade VII student with as many as 20 children, it is presented in table 4 .

Table 4. Student Response Results

\begin{tabular}{ccc}
\hline Aspect & Average & Description \\
\hline User & $4,36$. & Very decent \\
\hline
\end{tabular}

Based on the results of small field trials, it can be noted that the learning media MATMINO has an average end of 4.36. The assessment results in a range of $X \geq 4.21$ with a description very decent. During the student group trials, there are no obstacles in the implementation and the atmosphere is conducive. The comments and suggestions from student's response after using the learning media MATMINO is fun, interesting and cool game, can be played when feeling bored or rest. 


\section{Evaluation}

This step is to know the feasibility of the product that is produced, the Learning Media of MATMINO (mathematics Domino) in class VII includes algebra material. The evaluation stage, the researcher will evaluate the four previous stages. The analysis phase of necessity can be concluded that the learning Media game does not exist, the teachers use the Microsoft presentation software to assist the learning process, according to the characteristics of students who like to play. The design stages include making prototype media lessons, questions, game rules and guidebooks. The development stages include product creation, validation and revision. The validation phase includes media experts, material experts. The media experts by two mathematics education lecturers who give an online assessment earned an average of 4.375. The assessment results of the media experts entered in the range of $X \geq 4.21$ with the category of very decent, get advice so that the Media learning continues to economic aspects. Researchers proceed to the economical aspect by providing the form of softcopy so that the Media can be owned by all teachers and users. The material members are two professors of mathematics education and two teachers who give an online assessment get an average of 4.34. The assessment results of the media experts entered in the range of $X \geq 4.21$ with the category very decent, with revisions as per the suggestion. The algebra problem added an opening sentence for several types of questions and corrected the writing of the division symbols for the same. Stage of to know the feasibility of Media learning after being validated by material experts and media experts. Students are given an online poll containing items of feasibility response to the mathematical Media Domino. Student Assessment results earned an average of 4.36. The results of student's studies in the $X \geq 4.21$ range with the category very decent, some students comment about this product are fun, interesting and can help in learning mathematics. The conclusion of the assessment of media experts, material experts and students suggest that the media of mathematics Domino learning is well worth using.

\section{Discussion}

Researchers are able to successfully present the learning of Domino math media that has been validated by experts with excellent value and worth using. Research similar products in developing the media game Domino quite a lot (Herawati, 2017; Wulan, Dibia, \& Suarjana, 2013; Sahman, 2019; Amir \& Wardana, 2017; Harsono \& Prihatnani, 2018; Sidarta \& Yunianta, 2019; Bilda, 2016; Hebden, 2011; Halim, 2020; Khalidiyah, 2017; Nugraha, A. \& Rafidiyah, 2019; Veni Melina, 2017; Gough, 2015)

Math Game Domino has an educational element that can be used to educate and can be used in a fun and exciting mathematical learning process. Math Game Domino is a game that is inspired by a game of Domino in general that combined with the giving of motivational sentences on the back of the card. This game that makes this math Domino game is different from the Domino games in general and the game dominoes that have been used as learning Media (Nugraha \& Rafidiyah, 2019).

Domino's mathematics is designed and developed with a slight modification so that students can focus on learning and not eliminate the gameplay of the Domino itself. The modifications included in this Domino math game include each of the back cards given the motivational sentences to build the student spirit. No previous studies have given the motivational sentence on the Domino card (Harsono \& Prihatnani, 2018). The design display of the back of the card can be seen in Figure 1 that distinguishes the motivation sentence on MATMINO design. 


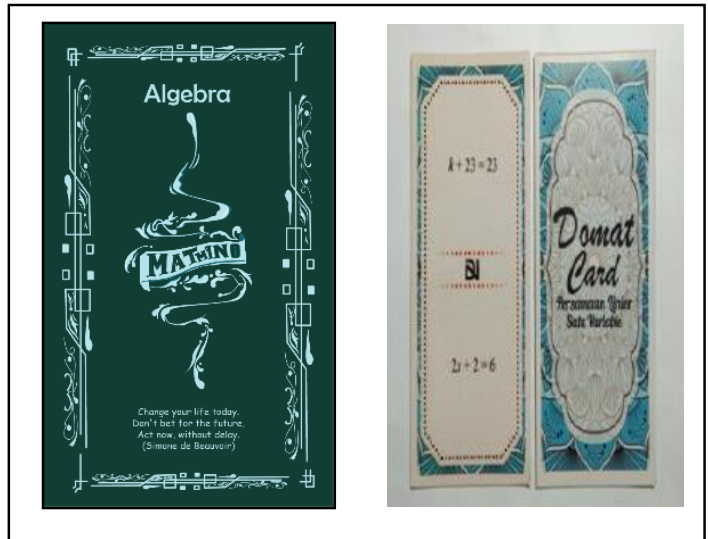

Figure 2. Design Differences MATMINO and DOMAT

The problems used in the game are related to algebraic material. This game is designed with the creation of problems that comply with the basic competencies from the easy difficulty level to the difficult to be equipped with the story, the previous product problem is used only a number (Nugraha \& Rafidiyah, 2019) and given the obvious instructions and the purpose of the question on algebraic material. The difference can be seen in Figure 3. Expected in this game the students will be motivated to complete each of the questions gained. This Domino math game is in the form of print media, so students can make it easy to play. The game card is designed with interesting colors.

\begin{tabular}{|c|c|c|c|c|c|c|c|}
\hline \multirow[t]{2}{*}{ Substitution } & Empty & 0 & 00 & $\begin{array}{c}00 \\
0\end{array}$ & $\begin{array}{l}00 \\
00\end{array}$ & $\begin{array}{c}00 \\
0 \\
00\end{array}$ & $\begin{array}{l}00 \\
00 \\
00\end{array}$ \\
\hline & 4 & $3 a+5 b$ & $6 x^{2}-11 x+5$ & $12 a^{3} b^{2}$ & $4 x+6$ & $3 a^{2}+6 b+9$ & $2 a^{2}+13 b+15$ \\
\hline Question 1 & $\begin{array}{l}\text { The height of the ball } \\
\text { thrown vertically } \\
\text { upwards every second } \\
\text { meets the formula } \\
h(t)=\left(4 t-t^{2}\right) \mathrm{m} \text {. } \\
\text { The height of the ball } \\
\text { in the 2nd second is .. }\end{array}$ & $\begin{array}{l}\text { Proceeds from } \\
a-b+2 a+6 b \\
\text { is ... }\end{array}$ & $\begin{array}{l}\text { Simplify the } \\
\text { following algebraic } \\
\text { shapes } \\
(6 x-5)(x-1) !\end{array}$ & $\begin{array}{l}\text { Determine kpk } \\
\text { from algebraic } \\
\text { form } 4 a^{2} b \text { and } \\
3 a^{3} b^{2} !\end{array}$ & $\begin{array}{l}\text { Proceeds from } \\
\left(4 x^{2}+6 x\right) \div x \\
\text { is ... }\end{array}$ & $\begin{array}{l}\text { Proceeds from } \\
3\left(a^{2}+2 b+3\right) \\
\text { is ... }\end{array}$ & $\begin{array}{l}\text { Simplify the } \\
\text { following } \\
\text { algebraic shapes } \\
(2 a+3)(a+5) !\end{array}$ \\
\hline Question 2 & $\begin{array}{l}\text { Define similar ethnic } \\
\text { groups: } \\
\text { 1. } x^{3} \text { and } x^{2} \\
2.3 x^{3} y^{4} \text { and } 5 x^{4} y^{6} \\
3.2 x^{5} \text { and } 2 x^{3} \\
4.6 x^{3} y^{2} \text { and } \\
-3 x^{3} y^{2} \\
\end{array}$ & $\begin{array}{l}\text { Simplify the } \\
\text { following algebraic } \\
\text { shapes } \\
-3 a+5 b+6 a !\end{array}$ & $\begin{array}{l}\text { Simplify the } \\
\text { following algebraic } \\
\text { shapes } \\
\left(12 x^{2}-22 x+\right. \\
10) \div 2 \text { ! }\end{array}$ & $\begin{array}{l}\text { Proceeds from } \\
\left(6 a^{2} b\right) \times(2 a b) \\
\text { is... }\end{array}$ & $\begin{array}{l}\text { Proceeds from } \\
(10 x+4) \\
-(6 x-2) \\
\text { is ... }\end{array}$ & $\begin{array}{l}\text { Proceeds from } \\
3\left(a^{2}+3\right)+6 b \\
\text { is } \ldots\end{array}$ & $\begin{array}{l}\text { Simplify the } \\
\text { following } \\
\text { algebraic shapes } \\
2\left(a^{2}+6 a+\right. \\
7)+a+1 \text { ! }\end{array}$ \\
\hline Question 3 & $\begin{array}{l}\text { Proceeds from } \\
(4 x+16) \div(x+4) \\
\text { is... }\end{array}$ & $\begin{array}{l}\text { Simplify the } \\
\text { following algebraic } \\
\text { shapes } \\
11 a-3 b-8(a- \\
\text { b)! }\end{array}$ & $\begin{array}{l}\text { Simplify the } \\
\text { following algebraic } \\
\text { shapes } \\
\left(30 x^{2}-55 x+\right. \\
25) \div 5 \text { ! }\end{array}$ & $\begin{array}{l}\text { Proceeds from } \\
\left(48 a^{5} b^{3}\right) \\
\div\left(4 a^{2} b\right) \\
\text { Is... }\end{array}$ & \begin{tabular}{|l|} 
The length of a \\
rectangle is $3 \mathrm{~cm}$ \\
more than its \\
width. If the width \\
is $\mathrm{x} \mathrm{cm}$, the \\
circumference of \\
the rectangle in $x$ \\
is ... \\
\end{tabular} & $\begin{array}{l}\text { Simplify the } \\
\text { following } \\
\text { algebraic shapes } \\
\left(5 a^{2}+9 b+\right. \\
5)-\left(2 a^{2}+\right. \\
3 b-4) !\end{array}$ & $\begin{array}{l}\text { Simplify the } \\
\text { following } \\
\text { algebraic shapes } \\
\left(a^{2}+7 a+8\right)+ \\
\left(a^{2}+6 a+7\right) !\end{array}$ \\
\hline & & & & & & & \\
\hline
\end{tabular}



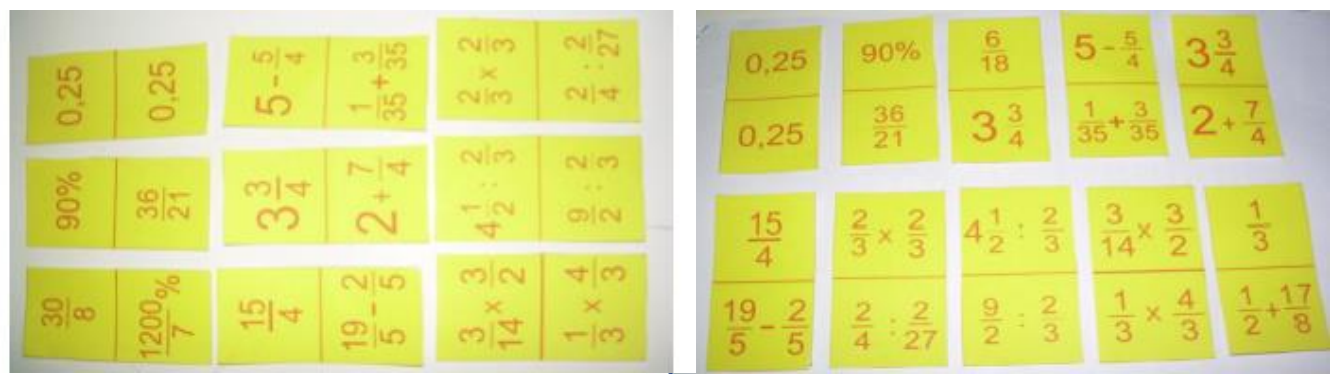

Figure 2. Differences in algebra in MATMINO and number operations

Based on the results of the student response questionnaire shows that the learning media of mathematics Domino is effective in supporting learning activities because it makes students feel happy and more passionate about studying mathematics on algebraic material. The effectiveness is in accordance with the opinion of Harsono \& Prihatnani (2018) about the effectiveness of a media, especially the game as a media learning, which is a game that is packaged appropriately in learning can serve as a positive media alternative to support learning activities. This game can help students increase motivation (Herawati, 2017; Sidarta \& Yunianta, 2019), a student who exercises creativity (Amir \& Wardana, 2017) and improve learning outcomes (Bilda, 2016; Wulan dkk., 2013;Sahman, 2019). Gough (2015) added a number of learning benefits while playing, among others, can get rid of the inhibiting seriousness, eliminating stress in the learning environment. The game of Domino as a learning medium is already widely used from early years school to higher education. Domino as a medium of learning not only on the subject of mathematics only, but is in the subject of Javanese language (Devi \& Maisaroh, 2017). The majority of Domino games are used for elementary school levels such as research (Veni, 2017; Sahman, 2019; Amir \& Wardana, 2017). The Domino Math game guide on the research was modified from previous research and a few additions to make it easier for players to understand.

Math Domino Learning Media according to the results of the validation and the student response poll has several advantages, among others, flexible because this game is a media learning the print product so it can be played anytime. The materials and problems in this media have been in accordance with the basic competencies that students must achieve, making memorization lessons more enjoyable and providing a new learning experience to the students. This Domino math is easy to play, the design and interesting colors do not make students bored.

The result of this learning media development of Domino math contains algebra material. This learning Media is equipped with a handbook that includes the rules of the game, the summary of the material, examples of questions and discussion of the questions available on the card MATMINO that can help students to facilitate the learning, recall the material and understand the questions provided. The development of this learning media researchers compiled materials based on the need's analysis. Students can repeat the material again in this handbook. Students can apply this MATMINO game to his friends. The contents of the materials and the questions provided on the learning media are based on basic competencies and consist of algebra material. The questions used for the game and the submission of the material in the researcher's guidebook use language that is easily understood by class VII students. The materials used in the Domino games are vocabulary on English subjects (Khalidiyah, 2017; Wing, 2015) and fractional on mathematical subjects (Hebden, 2011; Amir \& Wardana, 2017). This Domino math game can train students' recalls in material mastery, train and encourage students' courage to express their 
opinions, and train the mastery of concepts and understanding of learning materials. Media Learning Game Math Domino is expected to increase the motivation of students to help students in learning mathematics, help understand the material presented, and can change the mindset that learning is not only fixed on the book of subjects only. This Domino math product can be used repeatedly and stimulates children to learn to solve problems that are unnoticed by the students.

\section{CONCLUSIONS}

The conclusion of this research and development is as follows: the development of Domino Mathematics learning Media in algebra, system of equation and linear equality of one variable, and comparison using ADDIE's development model is analysis, design, development, implementation, and evaluation (assessment). Domino's mathematical feasibility on algebra, system of equations and linear inequality of one variable, and comparative based on material expert assessment earned very decent categories and based on media expert assessment get very decent categories too.

\section{REFERENCES}

Amir, M. F., \& Wardana, M. D. K. (2017). Pengembangan domino pecahan berbasis open ended untuk meningkatkan kemampuan berpikir kreatif siswa SD. Aksioma Jurnal Pendidikan Matematika FKIP Univ. Muhammadiyah Metro, 6(2), 178-188. http://dx.doi.org/10.36312/jisip.v3i1.635

Anggo, M., \& La Arapu. (2018). The use of mathematics teaching aids to train metacognition ability of Elementary School students. Journal of Physics: Conference Series, 1028(1), 1-6. https://doi.org/10.1088/1742-6596/1028/1/012143

Anwar, S. (2016). Peran pendidikan agama islam dalam membentuk karakter bangsa. AlTadzkiyyah: Jurnal Pendidikan Islam, 7(2), 157-169. https://doi.org/10.1017/CBO9781107415324.004

Attard, C., \& Holmes, K. (2020). It gives you that sense of hope: An exploration of technology use to mediate student engagement with mathematics. Heliyon, 6(11), 111. https://doi.org/10.1016/j.heliyon.2019.e02945

Bilda, W. (2016). Media kartu domino dalam pembelajaran matematika siswa SMP Negeri 1 Natar. Jurnal Prima, 5(2), 9-14. http://jurnal.umt.ac.id/index.php/prima/article/view/1473/927

Cinnirella, F., \& Schueler, R. (2018). Nation building: The role of central spending in education. Explorations in Economic History, 67(8), 18-39. https://doi.org/10.1016/j.eeh.2017.08.002

Devi, A. S., \& Maisaroh, S. (2017). Pengembangan media pembelajaran buku pop-up wayang tokoh Pandhawa pada mata pelajaran bahasa jawa kelas V SD. Jurnal PGSD Indonesia, $\quad 3(2)$. $\quad$ Retrieved http://ojs.upy.ac.id/ojs/index.php/jpi/article/view/985

Diego, M., Carlos, G., \& Jose, A. (2019). Adaptive learning objects in the context of ecoconnectivist communities using learning analytics. Heliyon, 5(11), 1-14. https://doi.org/10.1016/j.heliyon.2019.e02722

Donou-Adonsou, F. (2019). Technology, education, and economic growth in Sub-Saharan Africa. Telecommunications Policy, 43(4), 353-360. https://doi.org/10.1016/j.telpol.2018.08.005 
Eng, C. kin, \& Fah, C. gregory k han lay yoon. (2011). Students' attitudes to learning mathematics with technology at Rural Schools in Sabah, Malaysia. AtikanJurnal.Com, $1(2)$, 247-262. http://atikanjurnal.com/wpcontent/uploads/2011/12/07.chin_.cs_.ums_.my_.pdf

Gough, J. (2015). Stimulating mathematical thinking through domino games. Eric, 71(2), 20-22. Retrieved from https://eric.ed.gov/?id=EJ1093129

Halim, M. L. Al. (2020). Modifying domino cards to increase students' understanding of the use of possessive adjective at Junior High School. Jurnal Kependidikan, Pembelajaran, dan Pengembangan, 02(01), 71-79. Retrieved from http://ejournal.billfath.ac.id/index.php/karangan/article/view/47.

Hanushek, E. A., \& Woessmann, L. (2020). Education, knowledge capital, and economic growth. In The Economics of Education: Academic Press

Harsono, D. N., \& Prihatnani, E. (2018). Pengembangan permainan domat card pada materi sistem persamaan linier satu variabel. MAJU: Jurnal Ilmiah Pendidikan Matematika, 5(1), 1-13. Retrieved from http://ejournal.stkipbbm.ac.id/index.php/mtk/article/view/28

Hebden. (2011). Domino roulette. Washington, DC: U.S Patent and Trademark Office, 1(12), 1-7. Retrieved from https://patents.google.com/patent/US7976025B2/en

Herawati, E. (2017). Belajar siswa menggunakan media pembelajaran kartu domino matematika. Jurnal Nasional Pendidikan Matematika, 1(1), 66-87. https://doi.org/http://dx.doi.org/10.33603/jnpm.v1i1.254

Johnson, S. G. B., \& Steinerberger, S. (2019). Intuitions about mathematical beauty: a case study in the aesthetic experience of ideas. Cognition, 189(12), 242-259. https://doi.org/10.1016/j.cognition.2019.04.008

Karimah, R. F., Supurwoko, \& Wahyuningsih, D. (2014). Pengembangan media pembelajaran ular tangga fisika untuk siswa SMP/ MTs kelas VIII. Jurnal Pendidikan Fisika, 2(1), 6-10. Retrieved from http://www.jurnal.fkip.uns.ac.id/index.php/pfisika/article/view/3728

Khalidiyah, H. (2017). The use of domino game with picture in improving students vocabulary knowledge. Education and Language International Conference Proceedings Center for International Language Development of Unissula, 1(1), 349-358.

Law, K. M. Y., Geng, S., \& Li, T. (2019). Student enrollment, motivation and learning performance in a blended learning environment: The mediating effects of social, teaching, and cognitive presence. Computers and Education, 136, 1-12. https://doi.org/10.1016/j.compedu.2019.02.021

Leonard \& Wibawa, B. (2020). Development of teacher research competency training system in Indonesia : a need analysis. Universal Journal of Educational, 8(5), 2064 2070. https://doi.org/10.13189/ujer.2020.080544

Leonard, \& Nisa, K. K. (2020). Penerapan model pembelajaran team assisted individualization dengan strategi pembelajaran tugas dan paksa terhadap kemampuan pemecahan Masalah Matematika. Journal of Medives: Journal of Mathematics Education IKIP Veteran Semarang, 4(1), 111-127. https://doi.org/10.31331/medivesveteran.v4i1.967

Leonard, \& Wibawa, B. (2020). A training model based on collaborative research to develop teachers' research competence. International Journal of Innovation, Creativity and Change, 12(10), 592-608. Retrieved from https://www.ijicc.net/images/vol12/iss10/121037_Leonard_2020_E_R.pdf.

Lin, F. L., Wang, T. Y., \& Yang, K. L. (2018). Description and evaluation of a large-scale project to facilitate student engagement in learning mathematics. Studies in Educational Evaluation, 58, 1-9. https://doi.org/10.1016/j.stueduc.2018.03.001 
López-Fernández, D., Ezquerro, J. M., Rodríguez, J., Porter, J., \& Lapuerta, V. (2019). Motivational impact of active learning methods in aerospace engineering students. Acta Astronautica, 165(5), 344-354. https://doi.org/10.1016/j.actaastro.2019.09.026

Mahendra, I. W. E. (2017). Project based learning bermuatan etnomatematika dalam pembelajar matematika. Jurnal Pendidikan Indonesia, 6(1), 106-114. https://doi.org/http://dx.doi.org/10.23887/jpi-undiksha.v6i1.9257

Manullang, B. (2013). Grand desain pendidikan karakter generasi emas 2045. Jurnal Pendidikan Karakter, (1), 1-14. https://doi.org/10.21831/jpk.v0i1.1283

Mayangsari, S. N., \& Mahardhika, L. T. (2019). Characteristics of learning media that motivate. European Journal of Research in Social Sciences, 7(1), 56-64.

McGowen, M. A., \& Tall, D. O. (2013). Flexible thinking and met-befores: Impact on learning mathematics. Journal of Mathematical Behavior, 32(3), 527-537. https://doi.org/10.1016/j.jmathb.2013.06.004

Muhtadi, A. M. dkk. (2019). Analisis kemampuan komunikasi dan minat belajar matematis siswa SMP. Journal on Education, 1(2), 419-429. Retrieved from https://www.jonedu.org/index.php/joe/article/view/83/69

Novitasari, L., \& Leonard. (2017). Pengaruh kemampuan pemahaman konsep matematika terhadap hasil belajar matematika. Prosiding Diskusi Panel Nasional Pendidikan Matematika., $\quad 758-766 . \quad$ Retrieved from https://journal.lppmunindra.ac.id/index.php/repository/article/view/1952

Nugraha, A. G., \& Rafidiyah, D. (2019). Training of using domino card game to teach fraction for mathematics teachers at Junior High Schools in Banjar Regency. Comment: An International Journal of Community Development, 1(3), 67-70. Retrieved from http://journal.greenvisioneers.or.id/index.php/comment/article/view/46

Nugraha, A., \& Sundayana, R. (2014). Penggunaan alat peraga sebagai upaya untuk meningkatkan prestasi belajar dalam memahami konsep bentuk aljabar ada siswa kelas VIII di SMPN 2 Pasirwangi. Jurnal Pendidikan Matematika Mosharafa, 3(3), 133-141.

https://journal.institutpendidikan.ac.id/index.php/mosharafa/article/view/mv3n3_1/ 238

Nugroho, A. A., Putra, R. W. Y., Putra, F. G., \& Syazali, M. (2017). Pengembangan blog sebagai media pembelajaran matematika. Al-Jabar : Jurnal Pendidikan Matematika, 8(2), 197-203. https://doi.org/10.24042/ajpm.v8i2.2028

Ramli, F., Shafie, N., \& Tarmizi, R. (2013). Exploring Student's in-depth learning difficulties in mathematics through teachers' perspective. Procedia - Social and Behavioral Sciences, 97, 339-345. https://doi.org/10.1016/j.sbspro.2013.10.243

Ruff, S., \& Boes, S. (2014). The sum of all fears: the effects of math anxiety on math achievement in fifth grade students and the implications for school counselors. Georgia School Counselors Association Journal, 21(1). Retrieved from https://eric.ed.gov/?id=EJ1084441

Sahara, R., Mardiyana., \& Sari, R. (2017). Literatur study: Discovery learning teaching model trough somatic auditory visual intelectual approach in mathematic teaching. ICRIEMS Proceedings, 135-140. Retrieved from https://pdfs.semanticscholar.org/8f71/6131faa2fe6341d6b19bf20b76b77f73852d.p df.

Sahman. (2019). Meningkatkan hasil belajar matematika dengan penggunaan alat peraga domino pada siswa kelas V SDN Berani tahun pelajaran 2016/2017. Jurnal Ilmu Sosial dan Pendidikan, 3(1), 5-10. https://doi.org/http://dx.doi.org/10.36312/jisip.v3i1.635 
Sekuloska, J. D. (2014). Higher education and training as crucial pillars in creating the competitiveness of nation. Procedia - Social and Behavioral Sciences, 156(4), 241246. https://doi.org/10.1016/j.sbspro.2014.11.182

Serlina, \& Leonard. (2019). The role of aptitude treatment interaction instructional model with task and forced instructional strategy on student mathematical reasoning ability. Journal of Instructional Development Research, 1(1), 1-12. https://doi.org/http://dx.doi.org/10/30998/jidr.v1i1.1234

Setiawati, N. A. (2017). Pendidikan karakter sebagai pilar pembentukan karakter bangsa. Seminar Nasional Tahunan Fakultas Ilmu Sosial Universitas Negeri Medan, 1(1), 348-352. Retrieved from http://semnastafis.unimed.ac.id/wpcontent/uploads/2017/11/27.-Nanda-Ayu-Setiawati.pdf.

Sidarta, K. T., \& Yunianta, T. N. H. (2019). Pengembangan kartu Domano (domino matematika trigono) sebagai media pembelajaran pada matakuliah trigonometri. Scholaria: Jurnal Pendidikan Dan Kebudayaan, 9(1), 62-75. https://doi.org/10.24246/j.js.2019.v9.i1.p62-75

Sua, T. Y. (2013). Decolonization, educational language policy and nation building in plural societies: The development of chinese education in Malaysia, 1950-1970. International Journal of Educational Development, 33(1), 25-36. https://doi.org/10.1016/j.ijedudev.2012.01.009

Suciati, S., Septiani, I., \& Untari, M.F.A. (2015). Penerapan media Monosa (monopoli bahasa) berbasis kemandirian dalam pembelajaran di Sekolah Dasar. Mimbar Sekolah Dasar, 2(2), 175-188. https://doi.org/10.17509/mimbar-sd.v2i2.1328

Sudarsana, I. K. (2016). Peningkatan mutu pendidikan luar sekolah dalam upaya pembangunan sumber daya manusia. Jurnal Penjaminan Mutu, 1(1), 1. https://doi.org/10.25078/jpm.v1i1.34

Surat, I. M. (2016). Pembentukan karakter dan kemampuan berpikir logis siswa melalui pembelajaran matematika berbasis saintifik. Emasains, 5(1), 57-65. Retrieved from https://ojs.ikippgribali.ac.id/index.php/emasains/article/view/20

Veni Melina, F. A. (2017). The development of domino nusantara conservation media for students iv grade Elementary School of Purwoyoso 01 Semarang. Elementary School Teacher, 1(1), 44-48. Retrieved from https://journal.unnes.ac.id/nju/index.php/est/article/view/16530

Widyoko, E.P. (2012). Teknik Penyusunan Instrumen Penelitian. Yogyakarta: Pustaka Pelajar.

Wing, L. A. U. (2015). A Study on the effectiveness of using domino for consolidating vocabulary in upper Primary ESL Classrooms. The Hong Kong Institute of Education, 1-90.

https://repository.eduhk.hk/en/publications/a-study-on-the-effectiveness-of-usingdomino-for-consolidating-vo-4.

Wulan, L. P. D., Dibia, I. K., \& Suarjana, M. (2013). Penerapan model pembelajaran kooperatif tipe TGT berbantuan kartu domino untuk meningkatkan hasil belajar matematika siswa kelas IV. Mimbar PGSD Undiksha, 1(1). https://doi.org/http://dx.doi.org/10.23887/jjpgsd.v1i1.1445

Yosefa, B., \& Hesvi, W. (2014). Penggunaan strategi active learning melalui teknik groupto-group dalam pembelajaran matematika untuk meningkatkan kemampuan komunikasi matematis siswa. Jurnal Pengajaran Matematika Dan Ilmu Pengetahuan Alam, 19(1), 47-51. https://doi.org/10.18269/jpmipa.v19i1.423

Yuliati, Y. (2017). Literasi sains dalam pembelajaran IPA. Jurnal Cakrawala Pendas, 3(2), 21-28. https://doi.org/10.31949/jcp.v3i2.592 